\title{
Use of crushed fired clay ceramics in the production of mortars
}

\author{
I. Ioannou ${ }^{1}$, A. Ilia $^{1} \&$ M. Philokyprou ${ }^{2}$ \\ ${ }^{I}$ Department of Civil and Environmental Engineering, \\ University of Cyprus, Cyprus \\ ${ }^{2}$ Department of Town Planning and Housing, Ministry of Interior, Cyprus
}

\begin{abstract}
Construction and demolition waste (CDW) constitutes a major portion of total solid waste production in the world. While in many countries reuse and recycling of construction materials is well established, in other countries, including Cyprus, most CDW is landfilled together with municipal solid waste (MSW). Given the scarcity of landfill space and the increasing costs of improved environmental protection involved in contemporary landfill engineering and management, it is obvious that action to reuse or recycle construction materials will positively address the environmental impact of the local construction industry. In this paper we present the results of a laboratory study on the use of crushed fired clay ceramics, as a replacement for cement, in the production of mortars. We report on the physico-mechanical characteristics of these mortars and we reveal the most important factors that determine their strength and workability.
\end{abstract}

Keywords: fired clay ceramics, mortars, porosity, compressive strength, flexural strength.

\section{Introduction}

Construction and demolition waste (CDW) constitutes a major portion of total solid waste production in the world. In the United States, the annual CDW production exceeds 136 million tons [1], while in Europe, it accounts for approximately $40-50 \%$ of the entire waste stream [2]. The increasing production of CDW causes severe ecological and environmental problems. In order to solve 
these problems, it is recommended to try and feed back CDW in construction activities in the form of recycled materials.

Reuse and recycling of construction materials and components is well established in some countries. However, much of the recycled material is used in a low value-added form, such as a substitute for newly quarried (primary) aggregates in certain lower grade applications, most notably engineering fill and road sub-base. The use of recycled materials in new concretes and mortars [3-6] is much less common and technically more demanding. Increasing the use of recycled materials in these applications is a step forward in positively addressing the environmental impact of the construction industry.

In Cyprus, most CDW has traditionally been landfilled, frequently in the same landfills that are used to dispose municipal solid waste (MSW). Given the scarcity of landfill space and the increasing costs of improved environmental protection involved in contemporary landfill engineering and management, it is obvious that action to reuse or recycle CDW will reduce the proportion going to landfill, thereby relieving the pressures on MSW disposal.

The main objective of this paper is to present the results of a laboratory study on the use of crushed fired clay ceramics (bricks and roofing tiles) in the production of mortars. The physico-mechanical characterisation of the test mortars provides evidence of the suitability of crushed fired clay ceramics as a cement replacement and reveals the most important factors which determine the strength and workability of the end-products.

\section{Materials and methodology}

Several mortar mixes (Table 1) were designed in the laboratory using variable water/binder $(\mathrm{w} / \mathrm{b})$ ratios.

Table 1: $\quad$ Experimental mortar mix-designs.

\begin{tabular}{|c|c|c|c|c|c|c|c|}
\hline \multirow[b]{2}{*}{ Sample } & \multicolumn{2}{|c|}{ Ceramic Powder } & \multicolumn{2}{|c|}{ Aggregate } & \multirow[b]{2}{*}{$\mathrm{w} / \mathrm{b}$} & \multirow[b]{2}{*}{$\begin{array}{l}\text { Flow } \\
(\mathrm{mm})\end{array}$} & \multirow[b]{2}{*}{$\begin{array}{c}\text { Curing } \\
\text { Conditions }\end{array}$} \\
\hline & Type & $\begin{array}{l}\text { Particle Size } \\
\qquad(\mu \mathrm{m})\end{array}$ & $\mathrm{S} 1$ & $\mathrm{~S} 2$ & & & \\
\hline M1 & $\mathrm{CP} 1$ & $0-150$ & + & + & 0.9 & 180 & Wet burlap \\
\hline M2 & $\mathrm{CP} 2$ & $0-150$ & + & + & 0.9 & 175 & Wet burlap \\
\hline M3 & $\mathrm{CP} 3$ & $0-150$ & + & + & 0.9 & 175 & Wet burlap \\
\hline M4 & CP4 & $0-150$ & + & + & 0.9 & 165 & Wet burlap \\
\hline M5 & $\mathrm{CP} 4$ & $0-150$ & + & & 1.0 & 200 & Env. Chamber \\
\hline M6 & CP4 & $0-150$ & + & & 0.9 & 169 & Env. Chamber \\
\hline M7 & CP4 & $0-150$ & + & & 0.8 & 143 & Env. Chamber \\
\hline M8 & CP4 & $0-150$ & + & & 0.7 & 118 & Env. Chamber \\
\hline M9 & CP4 & $0-63$ & + & & 0.8 & 150 & Env. Chamber \\
\hline M10 & CP4 & $63-75$ & + & & 0.8 & 146 & Env. Chamber \\
\hline M11 & $\mathrm{CP} 4$ & $75-150$ & + & & 0.8 & 120 & Env. Chamber \\
\hline
\end{tabular}


In all cases, the binder elements comprised hydrated lime, in compliance with EN 459-1:2001 [7], and ceramic powder in a 1/1 (w/w) ratio. Four different types of ceramic powder were originally used in the mix-designs. The powders were produced in the laboratory by crushing and grinding broken and distorted bricks or roofing tiles supplied by a local manufacturer. For crushing, a laboratory jaws crusher (MATEST A092) was used, while for grinding a vibrating cup mill (Fritsch Pulverisette 9) was utilised. Table 2 provides details about the origin of the four ceramic powders used.

Table 2: $\quad$ Fired clay ceramic powder origin.

\begin{tabular}{|l|l|}
\hline $\mathrm{CP} 1$ & Bricks fired at $850^{\circ} \mathrm{C}$ \\
\hline $\mathrm{CP} 2$ & Roof tiles fired at $850^{\circ} \mathrm{C}$ \\
\hline $\mathrm{CP} 3$ & Roof tiles fired at $930^{\circ} \mathrm{C}$ \\
\hline $\mathrm{CP} 4$ & Roof tiles fired at $950-970^{\circ} \mathrm{C}$ \\
\hline
\end{tabular}

In addition to the ceramic powder, two different types of fine calcareous aggregates (sands) were also used in the original designs, their difference mainly being their gradation. One of the sands (S1) comprised of particle sizes in the range $0-2 \mathrm{~mm}$, whereas the other (S2) had slightly bigger particles $(0-4 \mathrm{~mm})$. The binder/aggregate ratio was constant $(1 / 3 \mathrm{w} / \mathrm{w})$ in all cases.

The mixing of the aggregates and binder elements with tap water was mechanical and always uniform. The workability of the wet mixes was measured using a flow table in accordance to EN 1015-3 [8]. All the samples were compacted following the methodology described in EN 196-1:1995 [9]. It was considered critical to use the same batch preparation (i.e. mixing and compaction time) for all specimens to avoid any differences that might occur from batch to batch.

The specimens were cast in standardised prismatic steel moulds of dimensions $40 \times 40 \times 160 \mathrm{~mm}$. To prevent the mortar from sticking, the sides of the mould were prepared with oil prior to placing the wet mix in them. After casting, the moulds containing the specimens were covered with a glass plate to prevent loss of water by evaporation. Specimens were removed from the moulds after 7 days. Between casting and testing, some of the specimens were placed in an environmental chamber at $23^{\circ} \mathrm{C}$ and $60 \%$ relative humidity $(\mathrm{RH})$ in order to cure, while others were simply kept covered with wet burlap.

The performance efficiency of the hardened experimental mortars was evaluated by a series of standardised testing procedures designed to measure their porosity and mechanical (compressive and flexural) strengths. The porosity was measured by vacuum saturation in accordance to the method described in [10]. Compression testing was performed in accordance to EN 1015-11:1999 [11] using an automatic servohydraulic system (CONTROLS ADVANTEST9) and a $250 \mathrm{kN}$ frame, while flexural testing was carried out using a Mecmesin MWD Manual Stand with a $10 \mathrm{kN}$ loadcell. 


\section{Results and discussion}

The experimental results (Table 3) provide evidence that, even in the absence of cement, some of the mortars (e.g. M2 and M4) produced using lime and crushed fired clay ceramic powder as binding elements develop satisfactory physicomechanical properties and are therefore suitable for use either as renders or as binding materials.

Table 3: $\quad$ Experimental results.

\begin{tabular}{|c|c|c|c|c|c|c|c|}
\hline \multirow{2}{*}{ Sample } & \multicolumn{3}{|c|}{$\begin{array}{c}\text { Compressive } \\
\text { Strength (MPa) }\end{array}$} & \multicolumn{3}{c|}{$\begin{array}{c}\text { Flexural Strength } \\
\text { (MPa) }\end{array}$} & \multirow{2}{*}{$\begin{array}{c}\text { Porosity } \\
(\%)\end{array}$} \\
\cline { 2 - 7 } & $28 \mathrm{~d}$ & $90 \mathrm{~d}$ & $180 \mathrm{~d}$ & $28 \mathrm{~d}$ & $90 \mathrm{~d}$ & $180 \mathrm{~d}$ & \\
\hline M1 & 0.5 & 1.0 & 2.0 & 0.2 & 0.5 & 0.9 & 37.1 \\
\hline M2 & 0.6 & 1.6 & 3.3 & 0.2 & 0.8 & 1.1 & 37.3 \\
\hline M3 & 0.6 & 1.1 & 1.7 & 0.3 & 0.5 & 0.8 & 38.6 \\
\hline M4 & 1.2 & 2.9 & 4.1 & 0.5 & 1.4 & 1.0 & 37.8 \\
\hline
\end{tabular}

While it is clear from the results that the compressive strengths of these mortars do not reach the levels of strengths achieved with the use of cement, they are still deemed suitable for use in new structures (mostly as renders). In fact, they can be used to provide a smooth brick-red finish that will require no painting (Fig. 1). As a result, not only will the mortar itself be a material with low embodied energy and an environmentally friendly character, but it will also help in avoiding the extra costs and energy normally required for the painting of a structure.

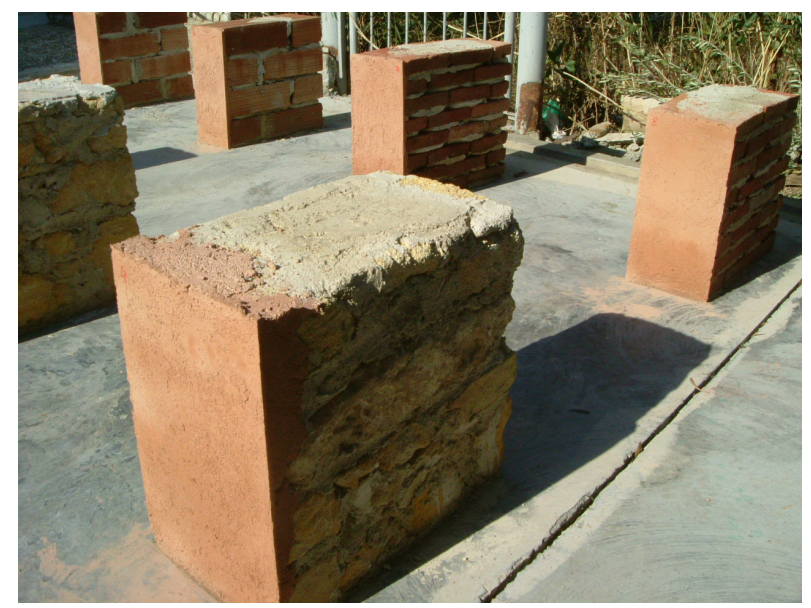

Figure 1: Pilot applications of crushed brick-lime mortar. 
The end-products are even better suited for use in historic structures as binding mortars. In fact, crushed fired clay ceramic-lime mortars are considered to be ideal for use in the restoration and conservation of ancient monuments and historic structures since they are fully compatible with the weak and porous traditional building materials. It is worth noting that, in the past, crushed brick mixed with lime had been used to produce mortars whenever pozzolanic materials were not available and a mortar with hydraulic properties (i.e. a mortar that could set and harden under water) was required. According to Baronio et al [12], King Solomon utilised such mortars to render cisterns used to collect water, while the Romans also used crushed brick-lime mortars in renderings exposed to severe climate, in floors where capillary rise of water was expected, in structures such as wells and aqueducts which were in permanent contact with water and in various horizontal structures (e.g. flat roofs) which were exposed to humid conditions. In the latest times of the Roman Empire, and especially during the Byzantine period, crushed brick-lime mortars also became very popular in Europe, Northern Africa and West Asia (Turkey).

The experimental results (Fig. 2) suggest that, besides the type, the degree of fineness of the ceramic powder also plays a very important role in the workability and strength development of the test mortars. This observation entirely agrees with evidence found in the literature [13-15] stating that the grain and fragments size of the crushed brick influences directly its hydraulic reactivity and consequently the physico-mechanical properties of crushed bricklime mortars. In fact, we show that the reactivity of the ceramic powder increases with a reduction in its particle size. When the latter is reduced below $63 \mu \mathrm{m}$ (sample M9), the powder reaches the highest level of activity and the compressive strength of the mortar produced exceeds $3.5 \mathrm{MPa}$ in 28 days.

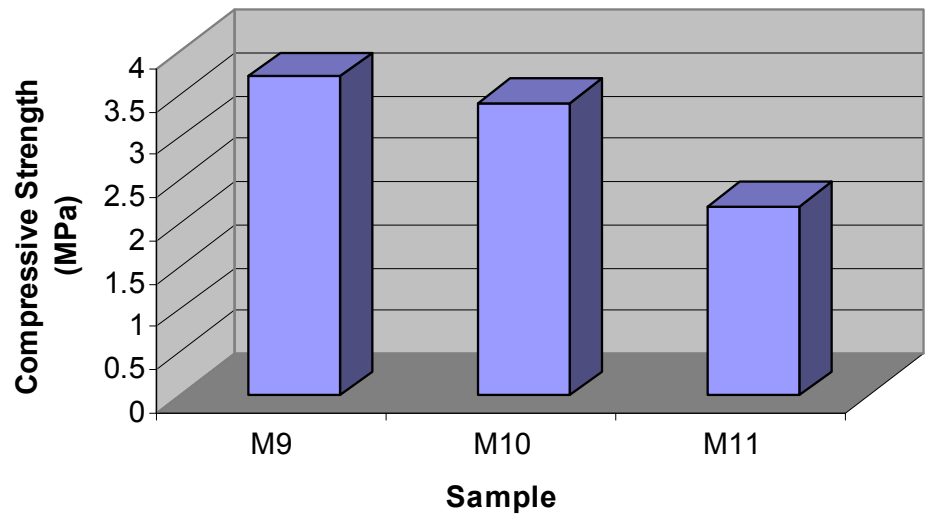

Figure 2: $\quad$ Increase in mortar compressive strength (28d) with reduction in ceramic powder particle size. 


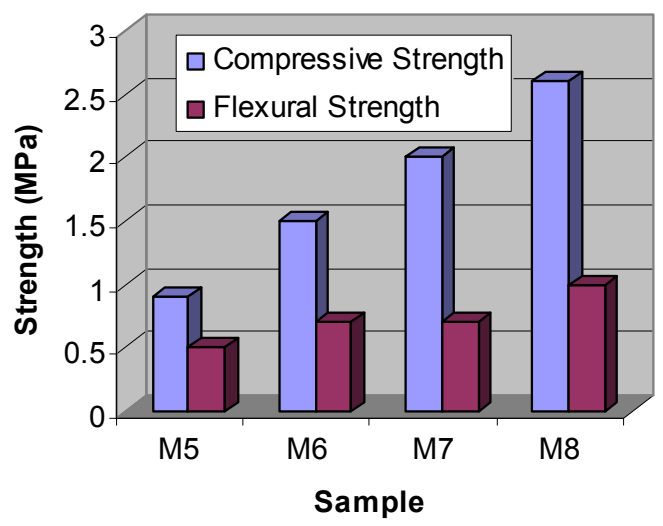

Figure 3: Reduction in compressive and flexural strengths with increase in $\mathrm{w} / \mathrm{b}$ ratio.

From the results, it is also evident that, while the compressive and flexural strengths of the experimental mortars increase significantly over time (Table 3), the addition of surplus water in the mix reduces the strengths radically (Fig. 3).

This is entirely reasonable since the addition of surplus water in the wet mix increases the number of voids which, in turn, affects the porosity of mortars. Porosity is inversely related to compressive strength. The relationship between these two fundamental mortar parameters may be described analytically as follows [16]:

$$
S=S_{0}(1-P)^{n}
$$

where $S$ is the strength, $S_{0}$ the theoretical strength at zero porosity, $P$ the porosity and $n$ a constant.

The porosities of the experimental mortars were estimated around 35-40\%. Even though such high porosities are indicative of mortars with a weak hydraulic to aerial character, it is worth mentioning that traditional materials in Cyprus, such as fired clay bricks and natural building stones have similar porosities. Hence, the experimental mortars are deemed compatible with these materials and may be used successfully in the conservation of local monuments.

\section{Conclusions}

The results presented in this paper show vividly that crushed fired clay ceramics have the potential to replace equivalent volumes of cement in the production of mortars. The most important factors which determine the strength and workability of these mortars are the $\mathrm{w} / \mathrm{b}$ ratio, the type and particle size of the ceramic powder. 
The use of recycled fired clay ceramics in mortar mix-design can contribute towards minimising energy consumption and the need for landfill space. In the future, the potential of crushed fired clay ceramics as concrete and mortar aggregates will also be evaluated. Such a study is expected to offer an environmentally friendly alternative to the use of natural aggregates, the sources of which are depleting at an increasing rate.

\section{References}

[1] U.S. Environmental Protection Agency, http://www.epa.gov

[2] Loizidou, M., Koroneos, C., Chardas, D., Bourka, A, Palekithrytis, T., Avramidis \& Chrysostomou, L. Sustainable Construction in Public and Private Works through IPP Approach - The SUSCON Project. Proc. of the $10^{\text {th }}$ International Conference on Environmental Science and Technology, University of the Aegean: Greece, 2007.

[3] Rao, A., Jha, K.N. \& Misra, S., Use of aggregates from recycled construction and demolition waste in concrete. Resources, Conservation and Recycling, 50, pp. 71-81, 2007.

[4] Poon, C.S., Kou, S.C. \& Lam, L., Use of recycled aggregates in molded concrete bricks and blocks. Construction and Building Materials, 16, pp. 281-289, 2002.

[5] Zakaria, M. \& Cabrera, J.G., Performance and durability of concrete made with demolition waste and artificial fly ash-clay aggregates. Waste Management, 16(1-3), pp. 151-158, 1996.

[6] Bektas, F., Wang, K. \& Ceylan, H., Effects of crushed clay brick aggregate on mortar durability. Construction and Building Materials, in press.

[7] EN 459-1, Building lime - Part 1: Definitions, specifications and conformity criteria, CEN: Brussels, 2001.

[8] EN 1015-3, Methods of test for mortar for masonry - Part 3: Determination of consistence of fresh mortar (by flow table), CEN: Brussels, pp. 4, 1999.

[9] EN 196-1, Methods of testing cement - Part 1: Determination of strength, CEN: Brussels, pp. 12-13, 2005.

[10] Hall, C. \& Hoff, W.D., Water Transport in Brick, Stone and Concrete, Spon Press: London and New York, pp. 9-13, 2002.

[11] EN 1015-11, Methods of test for mortar for masonry - Part 11: Determination of flexural and compressive strength of hardened mortar, CEN: Brussels, pp. 6, 1999.

[12] Baronio, G., Binds, L. \& Lombardini, N., The role of brick pebbles and dust in conglomerates based on hydrated lime and crushed bricks. Construction and Building Materials, 11, pp. 33-40, 1997.

[13] Bakolas, A., Biscontin, G., Contardi, V., Franceschi, E., Moropoulou, A., Palazzi, D \& Zendri, E., Thermoanalytical research on traditional mortars in Venice. Thermochimica Acta, 269/270, pp. 817-828, 1995.

[14] Moropoulou, A., Cakmak, A.S. \& Biscontin, G., Criteria and methodology to evaluate the Hagia Sophia crushed brick/lime mortars. PACT: Journal of 
the European Study Group on Physical, Chemical, Biological and Mathematical Techniques applied to Archaeology, 55, pp. 39-54, 1998.

[15] Papayianni, I., A holistic way of studying mortars and bricks of ancient masonries for manufacturing compatible repair materials. Proc. of the $4^{\text {th }}$ International Symposium on the Conservation of Monuments in the Mediterranean, Technical Chamber of Greece: Athens, pp. 265-274, 1997.

[16] Ioannou, I., Philokyprou, M., Papadouris, G. \& Kyriakou, K., Reproduction of hydraulic lime mortars based on the traditional production technology of ancient mortars from Cyprus. Proc, of the $1^{\text {st }}$ Euro-Mediterranean Regional Conference on Traditional Mediterranean Architecture Present and Future, RehabiMed: Barcelona, pp. 546-549, 2007. 